\title{
Pengaruh Pengungkapan Corporate Social Responsibility, Intensitas Modal, Dan Likuiditas Terhadap Penghindaran \\ Pajak
}

(Studi Empiris Pada Perusahaan Manufaktur Barang Konsumer Yang Terdaftar di Bursa Efek Indonesia Periode 2016-2019)

\author{
Tri Agustina ${ }^{1}$, Mohamad Zulman Hakim ${ }^{2}$ \\ Universitas Muhammadiyah Tangerang ${ }^{1,2}$ \\ agustinaaina@gmail.com
}

\begin{abstract}
Abstrak: Penelitian ini bertujuan untuk mengetahui pengaruh corporate social responsibility, intensitas modal, dan likuiditas terhadap penghindaran pajak. Objek penelitian ini adalah perusahaan manufaktur sektor barang konsumer yang terdaftar di Bursa Efek Indonesia tahun 2016-2019. Penelitian ini dilakukan menggunakan sampel sebanyak 27 perusahaan terpilih yang terdaftar di Bursa Efek Indonesia. Penentuan sampel menggunakan metode purposive sampling dan kriteria yang telah ditentukan peneliti menggunakan desain hubungan kausal. Karena itu, analisis data yang digunakan adalah analisis statistik dan bentuk uji regresi linear berganda. Hasil penelitian ini menunjukkan bahwa secara parsial variabel corporate social responsibility, intensitas modal tidak berpengaruh terhadap penghindaran pajak, sedangkan likuiditas berpengaruh terhadap penghindaran pajak. Hasil uji simultan pada penelitian ini menentukan bahwa secara bersama-sama variabel corporate social responsibility, intensitas modal, dan likuiditas berpengaruh signifikan terhadap penghindaran pajak.

Kata kunci: penghindaran pajak, corporate social responsibility, intensitas modal, dan likuiditas
\end{abstract}

Dalam upaya mewujudkan kesejahteraan rakyat, pemerintah pusat maupun daerah harus meningkatkan pelayanan kepada masyarakat terdapat beberapa sektor diantaranya yaitu sektor kesehatan, pendidikan, pembangunan, sarana dan prasarana. Upaya tersebut tidak akan terealisasi apabila tidak memperhatikan pendanaan, untuk mewujudkan pelayanan-pelayanan tersebut. Salah satu pendapatan negara yang nantinya digunakan untuk pelayanan masyarakat diberbagai sektor tersebut adalah pajak.

Definisi pajak menurut Undang-Undang No.16 Tahun 2009 "Pajak adalah kontribusi wajib kepada negara yang terutang oleh orang pribadi atau badan yang bersifat memaksa berdasarkan Undang-Undang, dengan tidak mendapatkan imbalan secara langsung dan digunakan untuk keperluan negara bagi sebesar-besarnya kemakmuran rakyat". Pajak merupakan sumber pendanaan bagi perekonomian di Indonesia demi kemajuan dan kelestarian negara, kontribusi wajib tersebut dilaksanakan oleh rakyat. Kewajiban membayar pajak dapat dipaksakan hal ini dilakukan untuk meningkatkan kesejahteraan rakyat Indonesia.

Hampir seluruh penerimaan negara diterima dari sektor pajak, sesuai dengan Anggaran Pendapatan dan Belanja Negara penerimaan pajak mencapai $80 \%-90 \%$. Berikut merupakan data yang dipublikasikan oleh Pusat Badan statistik Kementrian Keuangan. 
Tabel 1. Penerimaan Negara Tahun 2016-2019 (Angka dalam Triliun Rupiah)

\begin{tabular}{|l|l|l|l|l|}
\hline Sumber Penerimaan & $\mathbf{2 0 1 6}$ & $\mathbf{2 0 1 7}$ & $\mathbf{2 0 1 8}$ & $\mathbf{2 0 1 9}$ \\
\hline Penerimaan Pajak & $1,246,1$ & $1.202,7$ & $1.546,7$ & $1.489,9$ \\
\hline $\begin{array}{l}\text { Penerimaan Bukan } \\
\text { Pajak }\end{array}$ & 386,9 & 269.1 & 273,8 & 250 \\
\hline Hibah & 2,3 & 3,3 & 2,0 & 1,4 \\
\hline Jumlah & $1.635,3$ & $1.475,1$ & $\mathbf{1 . 8 2 2 , 5}$ & $1.750,3$ \\
\hline Persentase & $94,8 \%$ & $85,4 \%$ & $87,1 \%$ & $80,4 \%$ \\
\hline
\end{tabular}

Sumber: www.kemenkeu.go.id (2018)

Berdasarkan tabel diatas dapat dilihat bahwa pada tahun 2016 Penerimaan Pajak sebesar Rp.1.246,1 triliun, dan terjadi peningkatan pada tahun 2018 sebesar Rp.1.546,7 triliun atau rata-rata dalam persentase penerimaan negara dari tahun ke tahun meningkat sebesar 86,9\%. Terjadi peningkatan tersebut sumber terbesarnya dari penerimaan pajak. Meningkatnya penerimaan Pajak pada tahun 2016 karena diberlakukannya kebijakan pengampunan pajak atau Tax Amnesty sebesar Rp.303,6 Triliun. Upaya untuk mengoptimalkan penerimaan pajak masih mengalami banyak kendala, salah satunya karena adanya aktifitas penghindaran pajak atau biasa disebut Tax Avoidance (Swingly \& Sukartha, 2015).

Penghindaran pajak sangat penting untuk diperhatikan karena merupakan suatu tujuan dalam sebuah perusahaan. Namun demikian, di Indonesia perusahaan bisnis merupakan salah satu wajib pajak dimana perusahaan yang berorientasi laba, yaitu perusahaan multinasional yang berusaha meminimalkan beban pajak. Menurut (Chairil Anwar Pohan, 2014:11) penghindaran pajak atau tax avoidance adalah upaya mengefisienkan beban pajak dengan cara menghindari pengenaan pajak dengan mengarahkannya pada transaksi yang bukan pajak. Di indonesia, peraturan khusus anti penghindaran pajak atau spesific anti avoidance rule terdapat pada Pasal 18 Undang-Undang Pajak Penghasilan Nomor 36 Tahun 2008. Peraturan ini merupakan upaya untuk meminimalisir praktik penghindaran pajak.

Salah satu faktor yang mendorong terjadinya upaya penghindaran pajak adalah sistem perhitungan pajak di Indonesia yang menggunakan sistem Self Assesment, yaitu perhitungan pajak yang memberikan kepercayaan kepada wajib pajak untuk menghitung sendiri wajib pajak terutang mereka. Namun dengan adanya kewenangan tersebut berpotensi menimbulkan perbedaan perhitungan dengan pihak otoritas pajak dan perbedaan perhitungan tersebut mengakibatkan ketidakpastian dalam memperkirakan pajak perusahaan sehingga mengarah pada tindakan penghindaran pajak (Wenny, 2015).

Fenomena penghindaran pajak sering ditemui dalam perusahaan besar yang berasal dari luar_negeri, salah satunya adalah Gucci. Gucci merupakan perusahaan terkenal yang memproduksi_berbagai macam fashion yang berasal dari Italia. Pada 5 Desember 2017 seperti yang dilansir oleh inews.id, menyatakan bahwa Gucci melakukan penghindaran pajak hingga miliaran dolar karena Gucci membayar pajak keuntungan 
penjualan di Italia ke negara lain yaitu negara Swiss, dimana negara Swiss memiliki aturan pajak yang lebih longgar sehingga Gucci dapat menghindari kewajiban pajak domestik sekitar Rp 22,5 triliun.

Otoritas Italia menerapkan kebijakan yang sangat tegas. Gucci dengan jelas melakukan pergeseran laba untuk mengurangi beban pajak dengan cara memindahkan labanya dari Italia dimana negara tersebut memungut tarif pajak dengan jumlah yang besar ke negara Swiss yang memiliki tarif pajak rendah. Meskipun pengalihan pajak umum dilakukan di Italia, tetapi banyak yang menyayangkan tindakan yang dilakukan oleh Gucci karena dinilai merugikan negara. Otoritas Italia saat ini menindak tegas siapa saja yang dengan sengaja melakukan tindakan penghindaran pajak yang membuat kerugian negara dalam jumlah besar.

Tindakan oleh Gucci merupakan tindakan yang menginginkan untuk membayar pajak seminimal mungkin dengan cara merencanakan penghindaran pajak. Penghindaran pajak yang dilakukan oleh perusahaan tersebut juga berkaitan dengan pihak pemilik modal dan manajemen di perusahaan. Hal ini sesuai dengan teori keagenan yang dikemukakan oleh Jensen dan Meckling (1976) yang 5 menyatakan bahwa pihak pemilik modal sebagai pihak principal dan manajemen sebagai pihak agent. Hubungan antara principal dan agent dalam keputusan yang diambil pihak manajemen untuk menjalankan tugasnya akan diawasi oleh pihak pemilik modal. Tindakan-tindakan yang telah diambil oleh manajemen Gucci untuk meminimalisir beban pajak dengan melakukan pengalihan laba dan memanfaatkan hutang afiliasi tanpa melihat dampak jangka panjangnya terhadap para pemilik modal.

Dampak dari fenomena ini adanya kesenjangan hubungan antara pihak agent dan principal, kesenjangan ini bisa diatasi dengan pihak principal mengeluarkan agency cost untuk mengawasinya. Corporate Social Responsibility (CSR) merupakan tanggung jawab sebuah perusahaan terhadap dampak dari keputusan-keputusan dan kegiatannya kepada masyarakat dan lingkungan sekitar. (Watson, 2014) menyatakan bahwa perusahaan yang mempunyai peringkat rendah dalam CSR dianggap sebagai perusahaan yang tidak bertanggung jawab secara sosial. Menurut Undang-Undang No. 40 tahun 2007 pasal 74 ayat (1) “ Perseroan yang menjalankan kegiatan usahanya di bidang dan/atau berkaitan dengan sumber daya alam wajib melakukan sosial dan lingkungan.

Intensitas modal menggambarkan seberapa besar perusahaan menginvestasikan asetnya dalam bentuk aset tetap. Menurut (Hakim, 2016) intensitas modal mencerminkan seberapa besar modal yang dibutuhkan untuk menghasilkan pendapatan. Kepemilikan aset tetap dapat mengurangi pembayaran pajak yang dibayarkan perusahaan karena adanya biaya depresiasi yang melekat pada aset tetap. Biaya depresiasi dapat dimanfaatkan oleh manajer untuk meminimumkan pajak yang dibayar perusahaan. Manajer akan melakukan investasi aset tetap dengan cara menggunakan dana menganggur perusahaan untuk 
mendapatkan keuntungan berupa biaya depresiasi yang berguna sebagai pengurang pajak (Hakim, 2016). Laba kena pajak perusahaan yang semakin berkurang akan mengurangi pajak terutang perusahaan (Fatimah, Anwar, Nordiansyah, \& Tambun, 2017).

Likuiditas merupakan kemampuan perusahaan untuk memenuhi kewajiban jangka pendeknya yang akan jatuh tempo. Artinya apabila ditagih oleh pihak lain terkait dengan kewajiban jangka pendeknya, maka perusahaan akan mampu memenuhi kewajiban atau hutang tersebut, terutama ketika jatuh tempo. Kewajiban jangka pendek beragam, baik itu hutang usaha, hutang bank, hutang jangka pendek, maupun hutang pajak (Hani, 2015:121).

Beberapa peneliti terdahulu mengenai Corporate Social Responsibility, Intensitas Modal, dan Likuiditas terhadap Tax Avoidance yaitu, penelitian (wijayanti, 2017) menyatakan CSR berpengaruh positif signifikan terhadap tax avoidance. Perusahaan yang melakukan penghindaan pajak, karena aktivitas CSR yang dilakukan akan menekan laba yang akan diperoleh sehingga pajak yang dibayarkan oleh perusahaan menjadi rendah. Sedangkan penelitian yang dilakukan (Shinta Budiati, 2016) menemukan bahwa Corporate Social Responsibility berpengaruh negatif signifikan terhadap tax avoidance. Perusahaan yang performa Corporate Social Responsibility yang tinggi memiliki rasa tanggung jawab yang tinggi sehingga perusahaan mengurangi tindakan penghindaran pajak karena di anggap tidak bertanggung jawab secara sosial.

Penelitian yang menghubungkan intensitas modal terhadap tax avoidance adalah (Shinta Budiati, 2016) Intensitas Modal berpengaruh positif signifikan terhadap penghindaraan pajak, karena asset tetap yang dimiliki oleh perusahaan dapat disusutkan dan penyusutan asset dapat dibebankan sebagai pengurang laba bagi perusahaan sehingga akan mengurangi beban pajak yang dibayarkan.Namun penelitian yang dilakukan oleh penelitian (Shinta Budiati, 2016) dan (Wiguna, 2017) bahwa capital intensity berpengaruh negatif signifikan terhadap penghindaran pajak.

Menurut penelitian yang dilakukan oleh (Budianti \& Curry, 2018) likuiditas berpengaruh positif karena Current Rasio berpengaruh positif terhadap Tax Avoidance artinya semakin tinggi tingkat utang jangka pendek perusahaan maka semakin tinggi pula indikasi suatu perusahaan untuk melakukan penghindaran pajak sedangkan penelitian yang dilakukan oleh Rosalia (Budianti \& Curry, 2018) menyatakan bahwa likuiditas tidak berpengaruh signifikan terhadap penghindaran pajak.

Penelitian ini dimotivasi dengan maraknya kasus penghindaran pajak di Indonesia. Selain itu, penelitian diatas menunjukan hasil yang tidak konsisten mengenai hasil penelitian dari penghindaran pajak sehingga penulis tertarik untuk melakukan penelitian lebih lanjut mengenai "Pengaruh Pengungkapan Corporate Social Responsibility (CSR). 
Intensitas Modal, dan Likuiditas Terhadap Penghindaran Pajak" Studi Empiris Perusahaan Manufaktur Sektor Industri Barang Konsumsi di Bursa Efek Indonesia (BEI) Tahun 2016-2019.

Berdasarkan ulasan tersebut, rumusan masalah penelitian adalah Apakah pengungkapan Corporate Social Responsibility berpengaruh terhadap penghindaran pajak, Apakah Intensitas Modal berpengaruh terhadap penghindaran pajak dan Apakah Likuiditas berpengaruh terhadap penghindaran pajak. Maka dari itu, tujuan dari penelitian ini adalah Untuk membuktikan secara empiris pengaruh Corporate social Responsibility terhadap penghindaran pajak, untuk membuktikan secara empiris pengaruh Intensitas Modal terhadap penghindaran pajak dan untuk membuktikan secara empiris pengaruh Likuiditas terhadap penghindaran pajak.

\section{METODE}

Jenis data yang digunakan dalam penelitian ini merupakan data sekunder. Tempat penelitian yang digunakan untuk mengambil data sekunder ini diperoleh dari laporan keuangan dan laporan tahun perusahaan manufaktur barang Konsumer di Bursa Efek Indonesia (BEI) dengan waktu penelitian dari tahun 2015 sampai dengan 2018. Data di peroleh dari situs resmi BEI www.idx.co.id.

Tabel 2. Operasional Variabel

\begin{tabular}{|c|c|c|c|}
\hline No. & Variabel & Indikator & Skala \\
\hline 1. & $\begin{array}{l}\mathrm{Y}=\text { Tax } \\
\text { Avoidance }\end{array}$ & $\begin{array}{l}\text { ET } \\
=\frac{\text { Beban Pajak Penghasilan }}{\text { Laba Sebelum Pajak }}\end{array}$ & Rasio \\
\hline 2. & $\begin{array}{l}\mathrm{X} 1= \\
\text { Corporate } \\
\text { Social } \\
\text { Responsibility }\end{array}$ & $\operatorname{CSRIj}=\frac{\sum \mathrm{xij}}{\mathrm{nj}}$ & Rasio \\
\hline 3. & $\begin{array}{l}\mathrm{X} 2= \\
\text { Intensitas } \\
\text { Modal }\end{array}$ & $\begin{array}{c}\text { Rasio Intensitas Aset Tetap } \\
=\frac{\text { Total Aset Tetap }}{\text { Total Aset }}\end{array}$ & Rasio \\
\hline 4. & $\begin{array}{l}\text { X3= } \\
\text { Likuiditas }\end{array}$ & $\begin{array}{l}\text { Rasio Lancar }(\text { CR }) \\
=\frac{\text { Aset Lancar }}{\text { Kewajiban Lancar }}\end{array}$ & Rasio \\
\hline
\end{tabular}

Metode yang digunakan dalam pengambilan sampel adalah metode purposive sampling. Purposive sampling adalah metode pengambilan sampel yang disesuaikan dengan kriteria tertentu agar sampel yang terpilih lebih representatif (Sugiyono, 2018:85). Berikut adalah kriteria-kriteria pengambilan sampel menggunakan metode purposive sampling dalam penelitian ini: 
a. Perusahaan manufaktur sektor barang konsumer yang terdaftar (listing) di BEI selama periode penelitian.

b. Perusahaan manufaktur sektor barang konsumer yang mempublikasikan laporan keuangan secara berturut-turut selama 31 Desember 2016 sampai dengan 31 Desember 2019.

c. Perusahaan yang menggunakan mata uang rupiah.

d. Perusahaan yang memiliki laba positif secara konsisten selama periode penelitian.

e. Perusahaan yang tidak IPO selama tahun penelitian.

f. Perusahaan manufaktur sektor barang konsumer yang laporan keuangannya memuat variabel penelitian yang akan diuji peneliti.

Tabel 3. Kriteria Pengambilan Sampel

\begin{tabular}{|l|l|l|}
\hline No & Kriteria Sampel & Jumlah \\
\hline 1. & $\begin{array}{l}\text { Perusahaan manufaktur sektor barang konsumer } \\
\text { yang terdaftar di BEl selama tahun 2015-2018 }\end{array}$ & 52 \\
\hline 2. & $\begin{array}{l}\text { Perusahaan yang IPO selama satu tahun } \\
\text { penelitian 2015-2018 }\end{array}$ & $(13)$ \\
\hline 3. & $\begin{array}{l}\text { Perusahaan yang tidak mempublikasikan laporan } \\
\text { keuangan tahunan selama penelitian berlangsung }\end{array}$ & $(4)$ \\
\hline 4. & $\begin{array}{l}\text { Perusahaan yang tidak memiliki nilai laba positif } \\
\text { secara konsisten selama tahun penelitian }\end{array}$ & $(8)$ \\
\hline & Jumlah sampel perusahaan & 27 \\
\hline & Jumlah Observasi (27 x 4tahun) & 108 \\
\hline
\end{tabular}

Sumber: Bursa Efek Indonesia (diolah), 2019

Berikut ini nama-nama perusahaan sub sektor barang Konsumer yang telah memenuhi kriteria dan terpilih menjadi sampel penelitian berdasarkan purvosive sampling yang digunakan.

\section{HASIL}

Penelitian ini didesain untuk menguji secara empiris pengaruh pengungkapan Corporate Social Responsibility, Intensitas Modal, Likuiditas Terhadap Penghindaran Pajak pada perusahaan manufaktur Sub Sektor Barang Konsumer yang terdaftar di Bursa Efek Indonesia pada periode 2015 - 2018. Pemilihan sampel pada penelitian ini menggunaka metode purposie sampling yaitu atas dasar kesesuaian karakteristik sampel dengan kriteria yang telah ditentukan.

Data hasil penelitian ini berupa laporan keuangan yang digunakan untuk menghitung nilai yang dibutuhkan pada CSR, Intensitas modal, Likuiditas dan penghindaran pajak. Pada data sampel perusahaan manufaktur tersebut, terdapat data outlier atau data yang menyimpang jauh dari data lainnya dalam suatu rangkaian data. Sehingga, data outlier ini dihilangkan untuk menjadikan data menjadi tidak bias atau mencerminkan fenomena yang sebenarnya. Menurut (Ghozali, 2013:41) terdapat 4 penyebab timbulnya data outlier yaitu: 
1. Kesalahan dalam meng-entri data

2. Gagal menspesifikasi adanya missing value dalam program komputer

3. Outlier bukan merupakan anggota populasi yang kita ambil sebagai sampel, tetapi

4. Outlier berasal dari populasi yang kita ambil sebagai sampel, tetapi distribusi dari variabel dalam populasi tersebut memiliki nilai ekstrim dan tidak terdistribusi secara normal.

\section{Uji pengaruh Simultan (Uji Statistik F)}

Uji statistik $F$ pada dasarnya dilakukan untuk menguji signifikasi variabel independen terhadap variabel independen secara besama-sama. Berikut ini merupakan hasil dari uji statistik $F$ yang disajikan dalam Tabel:

Tabel 12. Hasil Uji statistik F

Coefficients $^{\mathrm{a}}$

\begin{tabular}{|c|c|c|c|c|c|c|}
\hline \multirow{2}{*}{\multicolumn{2}{|c|}{ Model }} & \multicolumn{2}{|c|}{$\begin{array}{l}\text { Unstandardized } \\
\text { Coefficients }\end{array}$} & \multirow{2}{*}{$\begin{array}{c}\begin{array}{c}\text { Standardized } \\
\text { Coefficients }\end{array} \\
\text { Beta } \\
\end{array}$} & \multirow[t]{2}{*}{$t$} & \multirow[t]{2}{*}{ Sig. } \\
\hline & & $B$ & Std. Error & & & \\
\hline \multirow{4}{*}{1} & $\begin{array}{l}\text { (Consta } \\
\text { nt) }\end{array}$ & .275 & .011 & & 25.946 & .000 \\
\hline & CSR & -.014 & .021 & -.070 & -.671 & .504 \\
\hline & CR & -.003 & .001 & -.282 & -2.682 & .009 \\
\hline & $\begin{array}{l}\text { Intensita } \\
\text { s Modal }\end{array}$ & -.012 & .011 & -.121 & $-1.161 \mid$ & .249 \\
\hline
\end{tabular}

Dari Hasil Uji F, hipotesis akan diuji dengan melihat tingkat signifikansi di bawah 0,05 maka hipotesis diterima. Tabel di atas menunjukkan bahwa tingkat signifikansi sebesar 0,038 di bawah 0,05. Hal ini berarti bahwa model dalam penelitian ini fit (sesuai) dan dapat digunakan untuk memprediksi variabel penghindaran pajak.

\section{A. Uji Hipotesis}

1. Hasil Uji Signifikansi Parameter Individual (Uji t)

Tabel 13. Hasil Model Penelitian

\section{Coefficients $^{\mathrm{a}}$}

\begin{tabular}{|c|c|c|c|c|c|}
\hline \multirow[t]{2}{*}{ Model } & \multicolumn{2}{|c|}{$\begin{array}{l}\text { Unstandardized } \\
\text { Coefficients }\end{array}$} & $\begin{array}{c}\text { Standardized } \\
\text { Coefficients }\end{array}$ & \multirow[t]{2}{*}{$\mathrm{t}$} & \multirow[t]{2}{*}{ Sig. } \\
\hline & B & Std. Error & Beta & & \\
\hline (Constant) & .275 & .011 & & 25.946 & .000 \\
\hline CSR & -.014 & .021 & -.070 & -.671 & .504 \\
\hline $1 \mathrm{CR}$ & -.003 & .001 & -.282 & -2.682 & .009 \\
\hline $\begin{array}{l}\text { Intensitas } \\
\text { Modal }\end{array}$ & -.012 & .011 & -.121 & -1.161 & .24 \\
\hline
\end{tabular}

Sumber: Data diolah dengan SPSS Versi 20

Berdasarkan hasil uji $\mathrm{t}$ dapat diketahui pengaruh antar masing-masing variabel independen terhadap variabel dependen yang dapat dijelaskan sebagai berikut:

a. Hasil pengujian Corporate Social Responsibility terhadap Penghindaran Pajak memiliki t hitung sebesar -671 dengan tingkat signifikan 0,504, hal ini menunjukan bahwa CSR 
berpengaruh negatif tidak signifikan terhadap penghindaran pajak, sehingga hipotesis $1(\mathrm{H} 1)$ ditolak.

b. Hasil pengujian Likuiditas terhadap penghindaran pajak memiliki t hitung sebesar $-2,682$ dengan tingkat signifikan 0,009. Hal ini menunjukkan bahwa Likuiditas berpengaruh positif signifikan terhadap penghindaran pajak. Sehingga hipottesis $2(\mathrm{H} 2)$ diterima.

c. Hasil pengujian Intensitas Modal terhadap penghindaran pajak memiliki t hitung sebesar -1,161 dengan tingkat signifikan 0,249, hal ini menunjukkan bahwa Intensitas Modal berpengaruh negafif tidak signifikan terhadap penghindaran pajak, sehingga hipotesis (H3) ditolak.

2. Uji Analisis Linear Berganda

Analisis ini untuk mengetahui arah Hubungan antara variabel independen dengan variabel dependen. Apakah masing-masing variabel indepanden berhubungan positif atau negatif dan untuk memprediksi nilai dari variabel dependen apabila nilai variabel independen mengalami kenaikan atau penurunan. Data yang digunakan biasanya berskala interval atau rasio.

Aregresi linear berganda untuk menguji pengaruh Corporate Social Responsibility, Likuiditas dan Intensitas Modal terhadap Penghindaran Pajak. Hasil analisis linear berganda dengan program SPSS 20 adalah sebagai berikut:

Tabel 13. Hasil Analisis Regresi Linear Berganda

Coefficients $^{\mathrm{a}}$

\begin{tabular}{|l|r|r|r|r|r|}
\hline \multirow{2}{*}{ Model } & \multicolumn{2}{|c|}{$\begin{array}{c}\text { Unstandardized } \\
\text { Coefficients }\end{array}$} & $\begin{array}{c}\text { Standardized } \\
\text { Coefficients }\end{array}$ & \multirow{2}{*}{ Sig. } \\
\cline { 2 - 4 } & \multicolumn{1}{|c|}{ B } & Std. Error & \multicolumn{1}{c|}{ Beta } & & \\
\hline \multirow{2}{*}{ (Constant) } & .275 & .011 & & 25.946 & .000 \\
CSR & -.014 & .021 & -.070 & -.671 & .504 \\
CR & -.003 & .001 & -.282 & -2.682 & .009 \\
Intensitas & -.012 & .011 & -.121 & -1.161 & .249 \\
\hline
\end{tabular}

a. Dependent Variable: ETR

Berdasarkan hasil pengujian pada tabel di atas perhitungan regresi linier berganda didapat hasil sebagai berikut:

Persamaan regresi tersebut dapat dijelaskansebagai berikut:

a. Konstanta

$$
Y=0,275-0,014 X 1-0,003 \times 2-0,012 \times 3+e
$$

Nilai konstanta yang diperoleh 0,275 , artinya jika Likuiditas berpengaruh terhadap ETR $(Y)$, sedangkan Corporate Social Responsibility, dan Intensitas Modal tidak berpengaruh terhadap $\operatorname{ETR}(\mathrm{Y})$ maka ETR $(\mathrm{Y})$ nilainya sebesar 0,275. 
b. Koefisien X1 untuk Corporate Social Responsibility

Koefisien regresi untuk variabel CSR sebesar -0,014 artinya bahwa setiap terjadi kenaikan CSR sebesar 1 kesatuan, maka ETR (Y) akan mengalami kenaikan -0,014 dengan asumsi variabel tetap.

c. Koefisien X2 untuk Likuiditas

Koefisien regresi untuk variabel Likuiditas sebesar -0,003 artinya bahwa setiap terjadi kenaikan Likuiditas sebesar 1 kesatuan, maka ETR (Y) akan mengalami kenaikan -0,003 dengan asumsi variabel tetap.

d. Koefisien X3 untuk Intensitas Modal

Koefisien regresi untuk variabel Intensitas Modal sebesar 0,012 artinya bahwa setiap terjadi kenaikan Intensitas Modal sebesar 1 kesatuan. Maka ETR (Y) akan mengalami kenaikan 0,012 dengan asumsi variabel tetap.

Berdasarkan hasil uji hipotesis dan koefisien determinasi di atas diperoleh hasil sebagai berikut:

\section{Pengaruh Corporate Social Responsibility terhadap penghindaran pajak.}

Hipotesis pertama yang diajukan pada penelitian ini adalah bahwa CSR berpengaruh negatif tidak signifikan terhadap penghindaran pajak, sehingga hipotesis ditolak. Hal ini dapat ditunjukan pada nilai sig. pada uji t sebesar -671 dengan tingkat signifikan 0,504 yang berarti lebih besarl dari 0,05. Dengan demikian, $\mathrm{H} 1$ diterima dan menunjukan bahwa semakin tinggi tingkat pengungkapan CSR, maka perusahaan semakin menyadari betapa pentingnya kontribusi perusahaan dalam membayar pajak.

Hal ini dikarenakan pajak yang nantinya akan diberikan dalam bentuk layanan dan fasilitas untuk kepentingan masyarakat. Jadi kewajiban perusahaan membayar pajak mencerminkan bahwa perusahaan tersebut perduli terhadap lingkungan sekitar dan keadaan sosial tempat dimana perusahaan tersebut beroperasi. Dengan demikian perusahaan yang menghindari beban pajak nya kurang perduli terhadap lingkungan sekitar.

Penelitian ini sejalan dengan penelitian yang dilakukan oleh Muadz Rizki Muzakki dan Darsono (2015), Ajeng Wijayanti, Anita Wijayanti, dan Yuli Chomsatu Samrotun (2016), dan Yogiswari dan Ramantha (2017) yang menyatakan bahwa variabel Corporate social Responsibility berpengaruh negatif terhadap secara signifikan.

\section{Pengaruh Likuiditas terhadap Penghindaran Pajak.}

Hipotesis kedua yang diajukan pada penelitian ini adalah bahwa Likuiditas berpengaruh positif signifikan terhadap penghindaran pajak, sehingga hipotesis ditolak. Hal ini dapat ditunjukan pada nilai sig. pada uji t sebesar dengan tingkat signifikan 0,009 yang berarti lebih kecil dari 0,05. Dengan demikian, $\mathrm{H} 1$ ditolak hal ini menunjukan bahwa kurangnya 
perusahaan untuk membayar beban pajaknya dari laba yang dihasilkan.

Bagi perusahaan mempertahankan likuiditas sangatlah penting. Likuiditas yang terlalu tinggi menggambarkan banyak uang tunai yang menganggur sehingga dianggap kurang produktif. Jika likuiditas terlalu rendah maka akan mengurangi tingkat kepercayaan kreditur terhadap perusahaan yang akan mengakibatkan para kreditur mengurani pinjaman modalnya.

Hasil penelitian ini sejalan dengan penelitian yang dilakukan oleh Ida Bagus Putu Fajar Adisamartha dan Naniek Noviari (2015) bahwa Likuiditas berpengaruh positif signifikan terhadap penghindaran pajak.

\section{Pengaruh Intensitas Modal Terhadap Penghindaran Pajak}

Hipotesis pertama yang diajukan pada penelitian ini adalah bahwa Intensitas Modal berpengaruh negatif tidak signifikan terhadap penghindaran pajak, sehingga hipotesis ditolak. Hal ini dapat ditunjukan pada nilai sig. pada uji t dengan tingkat signifikan 0,249 yang berarti lebih besar dari 0,05. Dengan demikian, $\mathrm{H} 1$ diterima, hal ini dikarenakan perusahan mampu memanfaatkan tarif penyusutan Aset tetap 5\% sampai dengan $50 \%$ sesuai dengan masa manfaatnya. Hal ini menunjukan bahwa selama periode penelitian menunjukan nilai yang positif yang artinya aset tetap bersih lebih tinggi, sehingga perusahaan dalam batas liquid dalam penggunaan aset perusahaan.

Penelitian ini sejalan dengan penelitian yang dilakukan oleh Muadz Rizki Muzakki dan Darsono (2015) bahwa Intensitas Modal berpengaruh negatif tidak signifkan terhadap penghindaran pajak.

\section{KESIMPULAN}

Penelitian ini bertujuan untuk mengetahui pengaruh pengungkapan CSR, Likuiditas dan Intensitas Modal terhadap Penghindaran Pajak. Penelitian ini menggunakan data sekunder berupa laporan tahunan dari perusahaan manufaktur sektur barang konsumer yang terdaftar di BEI tahun 2016-2019. Berdasarkan hasil analisis data dan pembahasan, maka dapat disimpulkan bahwa:

1. CSR secara negatif tidak signifikan terhadap penghindaran pajak. Hal ini menunjukan bahwa semakin tinggi tingkat CSR maka semakin baik terhadap penghindaran pajak.

2. Likuiditas secara positif dan signifikan terhadap penghindaran pajak. Hal ini menunjukan bahwa semakin tinggi tingkat pembayaran hutang jangka pendeknya maka semakin baik terhadap penghindaran pajak.

3. Intensitas Modal secara negatif dan signifikan terhadap penghindaran pajak. Hal ini menunjukan bahwa semakin tinggi tingkat Intensitas modal perusahaan maka semakin baik terhadap penghindaran pajak. 


\section{DAFTAR PUSTAKA}

Akuntansi, J., Ekonomika, F., Bisnis, D. A. N., \& Diponegoro, U. (2015). Insentif Pelaporan Dan Perencanaan Pajak Perusahaan (Vol. 4).

Budianti, S., \& Curry, K. (2018). Pengaruh Profitabilitas, Likuiditas, dan Capital Intensity Terhadap Penghindaran Pajak (Tax Avoidance). Prosiding Seminar Nasional Cendekiawan 4, Jakarta.

Chairil Anwar, P. (2014). Manajemen Perpajakan. PT Gramedia Pustaka Utama.

Daryono. (2017). Self Assessment System, Sistem Informasi Perpajakan, Penerapan E-Filing dan Sanksi Perpajakan Terhadap Kepatuhan Wajib Pajak Dengan Kualitas Pelayanan Sebagai Variabel Intervening (Studi Empiris Pada KPP Pratama Karanganyar) Self Assessment System, T. 103-109.

Dewi, Ni. Luh. Putu. Puspita., \& Noviari, N. (2017). Pengaruh Ukuran Perusahaan, Leverage, Profitabilitas Dan Corporate Social Responsibility Terhadap Penghindaran Pajak (Tax Avoidance). EJurnal Akuntansi Universitas Udayana, 21(1), 830-859.

Fajar Adisamartha, I., \& Noviari, N. (2015). Pengaruh Likuiditas, Leverage, Intensitas Persediaan Dan Intensitas Aset Tetap Pada Tingkat Agresivitas Wajib Pajak Badan. E-Jurnal Akuntansi, 13(3), 9731000.

Fatimah, Anwar, K., Nordiansyah, M., \& Tambun, S. P. (2017). Pengaruh Intensitas Modal, Kompensasi Eksekutif dan Kualitas Audit terhadap tindakan Penghindaran Pajak pada Perusahaan Manufaktur yang Terdaftar di Bursa Efek Indonesia. Prosiding Seminar Nasionasl ASBIS, 170-192.

Ghazali, I. (2014). Aplikasi Analisis Multivariate dengan Program IBM SPSS 21 (VII). Semarang: Badan Penerbit Universitas Diponegoro.

Hadi, N. (2011). Corporate Social Responsibility. Yogyakarta: Graha IImu. Ilyas, W.B., \& Priantara, D. (2013). Manajemen \& Perencanaan Pajak Berbasis Resiko. Jakarta: In Media.

Irianto, D. B. S., \& S.Ak, A. W. (2017). The Influence of Profitability, Leverage, Firm Size and Capital Intensity Towards Tax Avoidance. International Journal of Accounting and Taxation, 5(2), 33-41. https://doi.org/10.15640/ijat.v5n2a3

Jensen, M. C., \& Meckling, W. H. (1976). Theory of the Firm: Managerial. Journal of Financial Economics, 3, 305-360. https://doi.org/http://dx.doi.org/10.1016/0304-405X(76)90026-X

Kasmir. (2016). Pengantar Manajemen Keuangan (2nd ed.). Jakarta: Prenadamedia Group.

Martani, D., Siregar, S. V., Wardhani, R., Farahmita, A., \& Tanujaya, E. (2016). Akuntansi Keuangan Menengah. Jakarta: Salemba Empat.

Mir'atusholihah, Kumadji, S., \& Ismono, B. (2015). Pengaruh Pengetahuan Perpajakan, Kualitas Pelayanan Fiskus, dan Tarif Pajak Terhadap Kepatuhan Wajib Pajak. Jurnal Perpajakan, 876(March), 868-876. 
Mulyani, S., Darminto, \& N.p, W. endang. (2012). Pengaruh karakteristik perusahaan, koneksi politik dan reformasi perpajakan terhadap penghindaran pajak. Perpajakan, 66, 37-39.

Muzakki, M. R. (2015). Pengaruh Corporate Social Responsibility Dan Capital Intensity Terhadap Penghindaran Pajak. Pengaruh Corporate Social Responsibility Dan Capital Intensity Terhadap Penghindaran Pajak, 4(3), 445-452.

Natasya. (2016). NoPENGARUH AGRESIVITAS PAJAK TERHADAP CORPORATE SOCIAL RESPONSIBILIT: UNTUK MENGUJI TEORI LEGISTIMASI Title.

Nurkhin, A., Novanty, I., Muhsin, M., \& Sumiadji, S. (2018). The Influence of Tax Understanding, Tax Awareness and Tax Amnesty toward Taxpayer Compliance. Jurnal Keuangan Dan Perbankan, 22(2), 240-255. https://doi.org/10.26905/jkdp.v22i2.1678

Rahmawati, ayu. (2016). Pengaruh pengungkapan corporate social responsibility dan corporate governance terhadap tax avoidance. IOSR Journal of Economics and Finance, 3(1), 56. https://doi.org/https://doi.org/10.3929/ethz-b-000238666

Riyanto, B. (2001). Dasar-dasar Pembelanjaan Perusahaan (PBFE, ed.). Yogyakarta.

Saad, N. (2014). Tax Knowledge, Tax Complexity and Tax Compliance: Taxpayers' View. Procedia - Social and Behavioral Sciences, 109(1), 1069-1075. https://doi.org/10.1016/j.sbspro.2013.12.590

Sawitri, D., Dhewi, T. S., Hastiwibowo, C., Ridwan, A., \& Mulyono, S. (2019). THE EFFECT OF AMNESTY TAX POLICY AND TAX SANCTION ON TAXPAYER COMPLIANCE THROUGH MOTIVATION. 100(Icoi), 464-469.

Sudana, I. M. (2015). Manajemen Keuangan Perusahaan. Jakarta: Sinar Grafika.

Sugiyono. (2018). Metode Penelitian Kuantitatif Dan R\&D. Bandung: Alfabeta.

Swingly, C., \& Sukartha, I. (2015). Pengaruh Karakter Eksekutif, Komite Audit, Ukuran Perusahaan, Leverage Dan Sales Growth Pada Tax Avoidance. E-Jurnal Akuntansi, 10(1), 47-62.

Syafrida Hani. (2015). Teknik Analisa Laporan Keuangan. Medan: Salemba Empat.

Tiarawati, W. A. (2016). ANALISIS PENGARUH PENGUNGKAPAN CORPORATE SOCIAL RESPONSIBILITY TERHADAP TAX AVOIDANCE (PENGHINDARAN PAJAK) (Studi Empiris pada Perusahaan Manufaktur yang Terdaftar di BEI Periode 2009-2013). $\begin{array}{lll}\text { Jurnal Akuntansi Indonesia, } & 4(2),\end{array}$ https://doi.org/10.30659/jai.4.2.142-162

Waluyo. (2014). Perpajakan Indonesia. Jakarta: Salemba Empat.

Wiguna, I. P. P., \& Jati, I. K. (2017). Pengaruh Corporate Social Responsibility, Preferensi Risiko Eksekutif, Dan Capital Intensity Pada Penghindaran Pajak Fakultas Ekonomi Dan Bisnis Universitas 
Udayana (Unud), Bali, Indonesia. E-Jurnal Akuntansi Universitas Udayana, 21, 418-446.

Wijayanti, ajeng. (2017). Pengaruh Karakteristik Perusahaan, Good Corporate Governance Dan Corporate Social Responsibility Terhadap Penghindaran Pajak. Economica, 5(2), 113-127. https://doi.org/10.22202/economica.2017.v5.i2.383 